\title{
An Academic 'Glass Cliff'? Exploring the Increase of Women in Swedish Higher Education Management
}

\author{
By Helen Peterson *
}

Sweden has the highest percentage of female university Vice Chancellors in Europe. Some of the factors that have promoted women's representation in senior management in Swedish academia are: political pressure in the form of goals and policies, quantitative target agreements concerning women's representation, top level commitment to gender equality goals, and a network encouraging and supporting aspiring women managers. However, although women appear to break the glass ceiling, this paper sets out to investigate whether women are genuinely empowered in Swedish academia. Drawing on qualitative semi-structured interviews with 22 senior managers in Swedish higher education, the paper reveals some of the challenges facing manager-academics: increasing workload, role conflict and decreasing status and prestige. Situating women's increase in higher education management in a setting permeated by these challenges stimulates an analysis using theories about feminization of occupations and the metaphor 'glass cliff'. Feminization refers to how women's increase in an occupation often occurs simultaneously as it is transformed into a less prestigious work, with limited opportunities for advancement and weakened job security. The related concept 'glass cliff' describes a phenomenon when women are more likely to be appointed to precarious leadership roles in situations of turbulence and problematic organizational circumstances. The paper argues that women have been allowed to enter into management positions in higher education at the same time as these positions decline in status, merit and prestige and become more time-consuming and harder to combine with a successful scholarly career. Women are thus placed on an academic glass cliff. Keywords: Higher Education, management, women.

\section{Introduction}

Sweden is usually described as a country with overall high rankings regarding gender equality and has even earned the reputation as a 'pioneer in the gender equality area' (HSV 2011). For many years, Sweden has pursued an

*Associate Professor, Linköping University, Sweden. 
ambitious policy to promote gender equality in the higher education domain. However, there is still a long way to go before the goal of gender equality is achieved in Swedish higher education. As in other EU countries the Swedish higher education sector is characterized by the 'leaky pipeline' phenomenon (European Commission 2012). Although as many women as men get a doctoral degree only 22 per cent of the professors were women in 2011 (Statistics Sweden 2012). This means that Sweden is right on the European average when it comes to women's representation on the grade A level (European Commission 2012). Men are still appointed to professors to a greater extent than women, both 12 and 18 years after being awarded a doctor's degree (HSV 2011). In spite of policies that have tried to increase the proportion of female professors, the chances of a woman becoming a professor have not changed over time (Danell and Hjerm 2013).

Nonetheless, one area in which women have been very successful in Swedish academia is senior management. Sweden is the country with the highest per cent of female Vice Chancellors in Europe. The average proportion of female Heads of universities in the 27 EU countries is 10 per cent. This can be compared to 43 per cent in Sweden (European Commission 2012). In real numbers this translates into an increase in the number of women Vice Chancellors in Sweden from mere 5 in 1990 to 16 in 2010 (out of a total of 37). The proportion of women in Pro Vice Chancellor position in Swedish academia also increased between 1990 and 2010 - from 19 to 60 per cent. In real numbers this translates into an increase of women Pro Vice Chancellors from a mere 6 in 1990 to 25 in 2010 (Peterson 2011).

The fact that women have increased in number in management positions in higher education can be interpreted as an example of women breaking the so called 'glass ceiling' in academia (Gunluk-Senesen 2009). Some of the factors that can explain this are political pressure in the form of goals and policies, quantitative target agreements concerning women's representation in academia and top level commitment to gender equality goals. Another initiative is IDAS, a women's network for leadership in higher education. IDAS has promoted the concept that the institutions should work at the local level for the recruitment of more women for leading positions (HSV 2011).

This paper investigates whether other factors, besides gender equality work, policies and networks, have contributed to the change in gender composition of senior management positions in Swedish academia. The paper especially looks into skills requirements and whether these requirements have been redefined, thus asking: What is there in current higher education management that requires new skills, and why are women attracted and/or recruited to these management positions if the skills requirements are redefined? 


\section{Previous Research}

Women's increased access to management positions in Swedish higher education needs to be further contextualised. The time frame studied in this paper, 1990-2010, is a period characterized by a transformation of higher education. The Swedish higher education has had to face the same challenges as higher education in most other Western countries. During the last 20 years the Swedish universities have undergone a marketisation in order to compete on national and international student recruitment markets. In addition, the financial situation has radically been transformed with increased results-based competition between academic institutions for external funding (Ek et al. 2011). The higher education institutions are in some respects enjoying more autonomy in relation to the state, while the control in some other respects is becoming more rigorous. Ranking factors, performance monitoring measures, quality indicators and systems to evaluate effectiveness have been introduced together with procedures of self-assessment for teachers and researchers.

As a consequence of the restructuring, managerial roles in the Swedish higher education sector are becoming more complex and involving more timeconsuming administrative tasks (HSV 2004). 25 years ago academic management was largely symbolic and based on principles of collegiality while the employees enjoyed a great deal of autonomy and freedom (Barry et al. 2006). Today, universities are influenced by new managerialism and strategic management-principles involving profit-orientation, finance-driven decisions and marketing strategies. Managerialism entails a top-down management with reduced autonomy for employees to organize their own work and an emphasis on competition, efficiency and measurable performance (Deem 2006).

In summary, the educational restructuring presents new demands and challenges on managers in higher education. The challenges facing manageracademics have even been described in terms of 'extraordinarily complex issues and dilemma' and as 'unprecedented changes, shifts and developments in the structure, systems, strategies, functions, resources and services to the system' (Bosetti and Walker 2010: 18-19). Previous research has also suggested that the increasing number of women in academic management might be accompanied by a decline in the status and a de-skilling of management work (McTavish and Miller 2009).

Women's increase in Swedish higher education management can thus be placed in a turbulent occupational setting. In order to investigate whether the challenges facing manager-academics has had a negative influence on the attractiveness of the managerial positions and on the willingness of academics to take on managerial tasks the paper applies a certain theoretical framework. 


\section{Theoretical Framework}

This paper examines women's increased access to senior management positions in Swedish higher education using two theoretical concepts; 'feminization' and 'glass cliff'. The term 'feminization' usually refers to women entering the labour market or a specific occupation or position at an increasing rate (England and Boyer 2009). As Elianne Riska (2008) points out, it is a term that frequently is being used by different actors in different contexts with various meanings. Sometimes the expression 'feminization of an occupation' is strictly used to signify the numerical turn when the gender composition of an occupation switches from being male-dominated to becoming female-dominated and that women compose more than 50 per cent of the occupational practitioners. However, sometimes 'feminization' signifies an increase of women in an occupation or in a position regardless of the exact proportion of women or that women are reaching about a third in an organization (Adams 2005).

Although demographic feminization can be interpreted as a sign of increasing gender equality, feminization processes are complex and can be contradictory and not always strengthening women's position in the labour market (Bolton and Muzio 2008). Demographic feminization has also been linked to other aspects of the occupation involving status, pay, values, organization of work, professional practices and professional identity (Adams 2005). This type of feminization refers to how work discursively becomes marked as 'women's work' at the same time as it is transformed into a less prestigious work, with limited opportunities for advancement and weakened job security (England and Boyer 2009).

New skills requirements in occupations in combination with the gendering of skills, and how women and men respectively are expected to perform in accordance with these gendered skills, can explain demographic feminization (Riska 2008). Women's leadership style, presumed to be different from that of men, has been used as an argument to support the recruitment of women to management positions. New demands on a 'softer' approach to management, 'people skills' and a kind of transformative leadership are suggested to promote women as managers (Loughlin et al. 2012). The result is that women are recruited as 'change agents' to management positions and are expected to change the way leadership is performed and to make a positive contribution to organizational decision making (Young 2004).

The term 'feminization' can also denote a situation where women increase in number under turbulent conditions with economic, cultural and political restructuring (Deem et al. 2000). Demographic feminization can therefore also be interpreted as an example of how women enter management positions and end up on the so called 'glass cliff'. The 'glass cliff' is a metaphor used to describe a phenomenon when women are appointed to precarious leadership roles associated with an increased risk of negative consequences when a company is performing poorly and for example is experiencing profit falls, declining stock performance, and job cuts (Ryan and Haslam 2005). Previous 
research suggests that women are appointed to management positions under circumstances different from those of men. Women are more likely to be recruited to management positions under certain conditions - in situations of turbulence and problematic organizational circumstances (Ryan and Haslam 2005).

Has Swedish higher education management been feminized in this sense, i.e. transformed into an undervalued and less prestigious job, and is that why women are allowed to enter to these positions? Are women managers in higher education ending up on a 'glass cliff'?

\section{Methodology and Empirical Material}

The paper draws on qualitative interviews with 22 women in senior management positions in ten Swedish higher education institutions: four Vice Chancellors (Head of University), six Pro Vice Chancellors, five Deans (Head of Faculty) and seven Pro Deans. Fifteen of these women were professors; five were associate professors and two senior lecturers. Their age ranged from 44 to 64 and they had between 20 and 30 years experience of working as researchers, lecturers and managers in the Swedish academia. They came from different academic disciplines and faculties: law, art, medicine, theology, humanities, social sciences, technology, natural sciences and educational sciences.

The interviews were performed between February and April 2010. They lasted between 40 and 70 minutes and were semi-structured and fully transcribed. The semi-structured character of the interviews enabled attention to be paid to individual differences in the women's unique career narratives. The aim of the interviews was to learn more about policies, practices and processes that produce, reproduce and change vertical and horizontal gender segregation in higher education. The interviewed women were asked to describe their current work situation and their academic career, to reflect upon the academia as a work place for women from a more general point of view, and changes occurring over the past 20 years. They were also encouraged to develop their own ideas and opinions related to the increasing number of women in higher education management.

\section{Results and Analysis}

\section{The Transformation of Academic Management}

The interviewed women all had the same opinion concerning the increased workload for academic managers occurring during the past 20 years. They described the academic management role as becoming less ceremonial and less collegial but more administrative. According to a Pro Vice Chancellor, universities had changed 'radically' from being 'arenas for individual researchers' to 'hierarchical corporations' (Pro Vice Chancellor 1). One of the 
Vice Chancellors referred to academic management as being transformed into becoming more 'professionalized' (Vice Chancellor 4). This professionalization involved a distinct separation of the management role from the role as researcher. Academic management had become a separate career track parallel to the research track and the teaching track. This was a new way of thinking one of the women explained: 'Earlier the best researcher was supposed to be the manager due to the logic "if you are good at something [doing research] you are probably good at something else [managing]"' (Dean 5). Management positions in higher education, such as Head of department, Dean, Vice Chancellor, are temporary part-time jobs occupied by academics, or so called manager-academics (Dearlove 2002). These formal leadership roles are rotating rather than permanent. Traditionally, the manager-academic is elected by members of the faculty, often based on scholarly reputation rather than leadership skills (Winter 2009). However, according to the interviewed women, leadership skills started to become more important at the same time as scholarly achievements were becoming less important:

Before, these positions have been distributed according to year of service: 'It's your turn now'. Today, these positions require completely different work efforts and skills.(Pro Dean 3)

A consequence of this is changes in the skills requirements for effective management and the decreasing importance attributed to the Vice Chancellor being a (full) professor (Peterson 2011). A new kind of management was called for: 'We need another kind of leadership than 30 years ago' (Pro Dean 3).

The women thus constructed academic management 'today' different in relation to academic management 'in the past/before'. This is a contextualisation of their current work situation that relates to ongoing changes in higher education. The last 20 years the Swedish higher education sector has undergone a restructuring. Increased autonomy has been accompanied by intensified evaluation schemes, performance measures, profit-orientation, quality indicators and procedures of self-assessment (Barry et al. 2006).

\section{Increasing Workload}

One of the Deans explained that for her predecessor being a Dean was a 'routine job' (Dean 2). She compared it with the situation today: 'The workload for both Dean and Pro Dean has increased tremendously' (Dean 2). One of the Pro Vice Chancellors had worked in academic management positions for 10 years and described an 'increase in tempo' and that 'the pace is faster' and 'the demands are higher' (Pro Vice Chancellor 6). A Pro Dean with 30 years of experience of academic work described the changes she had witnessed: 'The administrative workload for a Pro Dean is really much heavier compared with before' (Pro Dean 1).

The managers' heavy workload was related to increasing 'extreme competitiveness' between higher education institutions, concerning 'external funding' (Dean 4). This situation meant that higher education institutions were 
'evaluated and assessed' and had to document everything, for example publications, to be able to compete (Pro Dean 3). The previously selfregulating professors, used to 'minding their own business' (Dean 4), now had to provide evidence that they contributed to reaching teaching and research targets, thereby producing substantial information in need of compilation and analysis. This was one aspect of the increasing administrative burden that influenced the academic management role.

For the academic managers this restructuring translated into work demands involving attending 'meetings more than 40 hours every week' (Pro Vice Chancellor 6) with committees, boards and different groups working on 'new policy proposals', 'following up annual reports', 'making strategic decisions' and 'producing an enormous amount of paper' (Dean 3). This is a very different description of the management role compared to how the Vice Chancellor in Swedish academia has been described in terms of the 'lonely and strong leader', 'charismatic', 'magnificent' and 'the Vice Chancellor is king!' (Fahlgren et al. 2007: 14-17). These descriptions reflect the masculine connotation of management and the link between management and masculinity that favour the promotion of men but marginalise women (cf. Wajcman 1998). The comparison with kings implies the status, prestige, respect and influence that are linked to the Vice Chancellor position. But these descriptions also constitute a management role that is self-evident for a man but not so for a woman. This is an environment in which women academic leaders have described their own experiences of being marginalised, viewed as 'odd' and not taken seriously (Nydahl 2007: 21).

The increasing workload resulted in a problematic work situation for the academic managers. Only one of the 22 interviewed women stated that she worked a regular full time week (i.e. 40 hours). Generally, they estimated their weekly hours of work to between 50 and 70. Answering the question how much she worked each week one of the interviewed Vice Chancellors exclaimed: 'Oh! All the time! I don't know. Fortunately I don't count but... well... an enormous lot of hours' (Vice Chancellor 4). These long hours qualify academic management to be considered as a so called 'extreme job' (Burke and Fiksenbaum 2009).

\section{Giving up a Prestigious Academic Career}

While all Vice Chancellors and some Pro Vice Chancellors were appointed to their position for six years on a full time basis the Deans and the Pro Deans had a three year part time contract allowing them to continue to do research and teach between 50 and 20 per cent of their working time. They were thus manager-academics (Dearlove 2002). In addition to being an academic manager they were supposed to carry out prescribed teaching and research functions within their discipline. However, to handle the combination of the management role and the scholarly role was challenging for the women: 'It's difficult to find time to do research' (Pro Dean 1). The work situation for these women manager-academics became characterized by role conflict (cf. Acker 
2012). Due to the character of management work, taking the shape of 'an awful lot of meetings' (Pro Dean 6), it was the academic work and the research tasks that were cut out from their busy schedule when time was scarce. A Pro Vice Chancellor had her management position on 50 per cent and was expected to do research 50 per cent of her working hours. However, she explained how problematic it was because of the workload as an academic manager: 'It's not unusual for me to have meetings from 8 am until $6 \mathrm{pm}$. It's not unusual' (Pro Vice Chancellor 2). Consequently, to work more than 40 hours each week became their only possibility to find time to do research.

The implication of this is that due to the time limited character of the management role, usually stretching between three and six years, the option to be a manager full time was not an attractive option, even if it would have decreased their workload and daily stress. Although academic management is becoming more professionalized and recognized as a separate career track it still has a temporary character. When the prestige linked to the management role diminishes this temporary character becomes more problematic because of the increasing competition for external funding. One woman, who was a Pro Dean on 80 per cent, explained that she in reality worked as a manager on 100 per cent. However, according to her it was 'impossible to let go of research even for just a year' (Pro Dean 6). Keeping up a relatively active research profile was important because academic managers need something 'to go back to' (Pro Dean 6) after their temporary management period comes to an end.

The role conflict was linked to the academics' professional identities and their commitment to their disciplines (cf. Floyd 2012; Winter 2009). One of the Vice Chancellors explained: 'I'm a researcher and a teacher. That's my profession. My whole professional identity is linked to it and it would be terribly difficult to let go' (Vice Chancellor 1). The professional identity as a researcher made some of the women hesitate to accept a management position because it 'involves giving up research' (Pro Vice Chancellor 1).

\section{Academic Management as a Glass Cliff}

Most of the women managers interviewed in this study followed the line of reasoning that appears in previous research on occupational feminization; linking demographic feminization to social and cultural feminization (cf. Adams 2005; Bolton and Muzio 2008; Deem et al 2000; Riska 2008). They described academic management as precarious and risky in several different aspects. Academic management positions were thus understood in terms of 'glass cliff' positions. One of the women for example came to the conclusion that men would continue to retreat from these management positions because of the increase in workload (cf. Coventry 1999):

Some of the men that would be next in line for a management position might not be interested in it anymore. Because it's too much hard work. (Pro Dean 3) 
The women's stories seem to provide evidence in support of a specific case of social and cultural feminization - when occupations become associated with women while simultaneously being deskilled and undervalued men will start to abandon the occupation and women will be allowed access. This is a type of situation that fits the definition of a 'glass cliff', i.e. when women are appointed to management positions under circumstances different from those of men - in times of organizational crisis when a company faces dramatic reduction in financial and/or reputational well-being (Ryan and Haslam 2005). One of the interviewed women established a link between the workload for managers and the number of women in the management position. According to her, women entering an occupation entail an almost automatic degrading of prestige. She explained: 'A management role is easily transformed into a servant role. Especially if many women hold the position' (Pro Dean 2). She continued to elaborate on the details of this kind of feminization process:

The academic management positions will follow the same pattern as we see everywhere. When women reach over 50 per cent the positions will lose all prestige. And then even more women are allowed to enter. (Pro Dean 2)

The problem with glass cliff appointments is that these management positions are associated with an increased risk of failure, with women managers at risk of being blamed for negative events. Another problem is that glass cliff appointments are particularly stressful for women and involve more interpersonal conflict (Haslam and Ryan 2005).

\section{Concluding Discussion}

The paper concludes that demographic feminization of senior management positions is intertwined with social and cultural feminization in the Swedish higher education sector. The results suggest that demographic feminization is not sufficient to claim that gender is not still structuring senior academic management. The paper highlights how important it is to distinguish different aspects of social and cultural feminization and how these aspects are linked to changes in gender relations, power, status, influence and management skills. Hence, structural and cultural barriers do not automatically change with the increasing number of women. The paper thus illustrates the stability with which prestige and status in the labour market is linked to gender relations.

The fact that women increase in number in management positions in higher education might be interpreted as an example of how women are breaking the so called 'glass ceiling' in academia (Gunluk-Senesen 2009). However, it might also be interpreted as an example of how women enter management positions and end up on the so called 'glass cliff' (Ryan and Haslam 2005). Using the concept of 'glass cliff' is one way to understand 
women's increase in higher education management, putting the emphasis on the context surrounding women's participation in academic management and highlighting the often problematic and difficult nature of the positions they are elected to.

It might be an oversimplification to assume that just because women enter management positions this will automatically entail a degrading of status and prestige. However, using the 'glass cliff' metaphor highlights how the management positions in higher education are depicted as no longer attractive career options compared to the research career-track. As the administrative workload increases, these management positions are becoming considered as: 'best left to the donkeys, so the stars can get on with their research' (Dearlove 2002: 270). From this follows that men might be less interested in an academic management career and instead more attracted to pursue the more prestigious career as 'excellent researcher' (Fahlgren et al. 2007).

The paper reveals some key challenges shaping the work situation for manager-academics, identified and expressed by the manager-academics themselves. These challenges were described as affecting the attractiveness of the managerial positions in academia negatively and discouraging academics from taking on managerial tasks. Getting academics into management positions throughout higher education is of pivotal importance but also an increasing problem (Floyd 2012). The higher education sector has been described as one of few work places where no one wants to be a manager. Becoming a manageracademic is not considered an attractive career route or a part of a successful academic career (Dearlove 2002). Recruiting academics to do managerial work is even more problematic during the restructuring of higher education that is now becoming a global educational trend. This restructuring involves 'unprecedented changes and shifts' to the academic system and adds further stress and pressure on academic-managers as they have to deal with 'extraordinarily complex issues and dilemma' (Bosetti and Walker 2010: 18$19)$.

Using the 'glass cliff' metaphor to understand the situation for women in higher education management draws attention to issues that are not just problematic from a gendered perspective. These issues concern the problematic working conditions that face academic managers in a general (or gender neutral) way. It is of vital importance that women as well as men in management positions are allowed to enjoy a more manageable and less stressful working environment. Senior managers play an important role in the development of the quality of research and teaching in the future higher education sector. More research is needed in order to understand the full complexity of the restructuring of higher education on a global scale and the consequences for the manager-academics and their work situation. 


\section{Acknowledgements}

The author wishes to thank the women who made this research possible by their participation. Research support from the Swedish Research Council for Health, Working Life and Welfare is gratefully acknowledged.

\section{References}

Acker, S. (2012). 'Chairing and caring: gendered dimensions of leadership in academe', Gender and Education 24(4): 411-428.

Adams, T. L. (2005). 'Feminization of Professions: The Case of Women in Dentistry', Canadian Journal of Sociology 30(1): 71-94.

Barry, J., Berg, E. \& Chandler, J. (2006). 'Academic Shape Shifting: Gender, Management and Identities in Sweden and England', Organization 13(2): 275298.

Bolton, S. \& Muzio, D. (2008). 'The paradoxical processes of feminization in the professions: the case of established, aspiring and semi-professions', Work, employment and society 22(2): 281-299.

Bosetti, Lynn and Walker, Keith (2010). 'Perspectives of UK Vice-Chancellors on Leading Universities in a Knowledge-Based Economy'. Higher Education Quarterly 64(1): 4-21.

Burke, R. J. \& Fiksenbaum, L. (2009). 'Are managerial women in 'extreme jobs' disadvantaged?' Gender in Management: An International Journal 24(1): 5-13.

Coventry, B. T. (1999). 'Do men leave feminizing occupations?' The Social Science Journal 36(1): 47-64.

Danell, R. \& Hjerm, M. (2013). Career prospects for female university researchers have not improved. Scientometrics 94(3): 999-1006.

Dearlove, J. (2002). 'A continuing role for academics: The governance of UK universities in the Post-dearing era', Higher Education Quarterly 56(3): 257-275.

Deem, R. (2003). 'Gender, Organizational Cultures and the Practices of ManagerAcademics in UK Universities', Gender, Work and Organization 10(2): 239-259.

Deem, R., Ozga, J. T. \& Prichard, C. (2000). 'Managing Further Education: Is it still Men's work too?' Journal of Further and Higher Education 24(2): 231-250.

Ek, A.-C., Ideland, M., Jönsson, S. \& Malmberg, C. (2011). 'The tension between marketisation and academisation in higher education', Studies in Higher Education, 1-14, iFirst Article.

England, K. \& Boyer, K. (2009). 'Women's Work: The feminization and shifting meanings of clerical work', Journal of Social History 43(2): 307-340.

European Commission. (2012). She Figures 2012. Statistics and Indicators on Gender Equality in Science. Luxembourg: Office for Official Publications of the European Communities.

Fahlgren, M., Norén, K. \& Sandström, B. (2007). Academic leadership today and in the future. Focus on recruitment of Vice Chancellors. Växjö: IDAS. [In Swedish].

Floyd, Alan (2012). "'Turning points": The Personal and Professional Circumstances That Lead Academics to Become Middle Managers'. Educational Management Administration and Leadership 40(2): 272-284. 
Gunluk-Senesen, Gulay (2009). 'Glass Ceiling in Academic Administration in Turkey: 1990s versus 2000s', Tertiary Education and Management 15(4): 305322.

HSV (2004). Leaders in Higher Education. About the Vice Chancellor Role and the Recruitment of Vice Chancellors. Stockholm: Högskoleverket (Swedish National Agency for Higher Education). [In Swedish].

HSV (2011). Academic careers for both women and men. Swedish National Agency for Higher Education. [In Swedish]

Loughlin, C., Arnold, K. \& Crawford, J. (2012). 'Lost opportunity. Is transformational leadership accurately recognized and rewarded in all managers?' Equality, Diversity and Inclusion 31(1): 43-64.

McTavish, D. \& Miller, K. (2009). 'Management, leadership and gender representation in UK higher and further education', Gender in Management 24(3): 178-194.

Nydahl, E. (2007). 'Without an obstinate gene I would never have tried!' Interviews with 62 successful women in higher education. Växjö: IDAS. [In Swedish]

Peterson, H. (2011). 'The gender mix policy - addressing gender inequality in higher education management', Journal of Higher Education Policy and Management 33(6): 619-628.

Riska, E. (2008). 'The Feminization Thesis: Discourses on Gender and Medicine', NORA - Nordic Journal of Feminist and Gender Research 16(1): 3-18.

Ryan, M. K. \& Haslam, S. A. (2005). The Glass Cliff: Evidence that Women are Over-Represented in Precarious Leadership Positions, British Journal of Management 16(2): 81-90.

Statistics Sweden (2012). Women and men in Sweden - facts and figures 2012.

Wajcman, J. (1998). Managing like a Man. Women and Men in Corporate Management. University Park, Pennsylvania: The Pennsylvania State University Press.

Winter, R. (2009). 'Academic manager or managed academic? Academic identity schisms in higher education', Journal of Higher Education Policy and Management 31(2): 121-131.

Young, P. (2004). 'Leadership and Gender in Higher Education: a case study', Journal of Further and Higher Education 28(1): 96-106. 